\title{
Practices and Challenges of Human Resource Development in Secondary Schools of Hadiya Zone, South Ethiopia
}

\author{
Dekeyo Lapiso ${ }^{1}$, Endale Berhanu ${ }^{2}$ \\ ${ }^{1}$ Yekatit 25/67 Secondary School, Hosaena, Ethiopia \\ ${ }^{2}$ Department of Educational Planning and Management, School of Education \& Behavioral Science, Wolaita Sodo University, Sodo, Ethiopia
}

Email address:

Lapisodekeyo@gmail.com (D. Lapiso), endaleberhanu45@yahoo.com (E. Berhanu)

To cite this article:

Dekeyo Lapiso, Endale Berhanu. Practices and Challenges of Human Resource Development in Secondary Schools of Hadiya Zone, South Ethiopia. European Business \& Management. Vol. 5, No. 3, 2019, pp. 24-41. doi: 10.11648/j.ebm.20190503.11

Received: April 12, 2019; Accepted: June 3, 2019; Published: July 9, 2019

\begin{abstract}
The main purpose of this study was to assess the practices and challenges of human resource development that have been carried out by Hadiya Zone Secondary Schools. To this effect, descriptive survey research design was employed by which questionnaires, interviews, and document analysis were used as instruments of data gathering. Both primary and secondary sources of data were used. The primary data sources were teachers, principals, supervisors, woreda education officers and zone education department experts. The school documents were used as a secondary data source. The data were collected from randomly selected 100 secondary school teachers including 21 principals and 3 supervisors were selected by using availability sampling and 9 Woreda Education Officers and 3 zone education department experts of Hadiya Zone were selected purposefully. A total of 136 respondents were included as subjects of the study. The findings of the study indicated the absence of the systematic needs assessment practices, no HRTD plan incorporated in strategic plans, objectives of TDP had not been well presented to trainees, no clear and transparent training and development criteria for selecting trainees and trainers. the practice of preparing and implementing TDPs had been constrained by low attention of top level educational leaders, lack of adequate budget, selection of inappropriate trainees and trainers, allocation of insufficient time. Based on the findings, the following conclusion was drawn; due to lack of systematic training and development needs assessment capacity and potentials of individuals had not been built for better future performance, appropriate individuals were neglected from the selection for the TDPs, secondary schools and education departments fail to measure the effects and benefits of the TDPs to the organization and the employees/ teachers and administrative staffs/. Based on the conclusions, the following are recommended: appropriate attention to be given to training and development needs assessment, allocation of necessary resources for TDP, planning TDP in association with strategic plan, arranging of induction/orientation programs, applying on-the-job methods, creating systematic monitoring and evaluating practices of TDP, arranging awareness creation programs and formulating clear and transparent TDP directives, and giving more emphasis on professional development rather than other activities in secondary schools and woreda education offices.
\end{abstract}

Keywords: Human Resource, Development, Secondary School and Zone

\section{Background of the Study}

School systems are the bases for the production and provision of qualified human resources. They are in charge of achieving educational objectives to shape pupils in accordance with the needs and interest of beneficiaries. It is generally believed that a society's future layer depends on the success of schools in effectively carrying out their objectives
(Krug, 1992).

There are a number of factors that contribute towards the success of an organization. These factors include capital, equipment, man power and the others. Of all these factors the human factor is the most significant one, since it is the people that use all other resources. Without productive efforts of workers, the material resources of an institution would be of no use. Furthermore, if the people are in a charge of these 
resources are not sufficiently qualified, and then the utilization of these resources would not optimal (Chandan, 2003).

Likewise, this fact holds true in school system. In relation to this concern, Ayalew states:

Human resources along with material, financial and time resources should efficiently be utilized if schools want to attain their goals effectively. Consequently, the efficiency of any organization could be realized through proper use of skills and talents of its existing human resources. In schools systems, teachers are very crucial in achieving school objectives. Because the strength of an education system, for the most part, determined by the quality of its teachers (Abiy, 2009).

Now a day, organizations operate in a complex and changing environment that highly influences their growth and expansions. To cope up with this changing environment and technological advancements, organizations need to develop and train their employees.

The quality of the human resources and the degree of its utilization determine the success of the organization (Heneman and Dyer, 1996). It is also believed that through training and development the organization can solve the problems of employees' obsolescence and make them up to date, motivated and committed.

Human resource development (HRD) is the process of determining the optimum methods of developing and improving the human resources of an organization and the systematic improvement the performance and productivity of employees through training, education and leadership for the mutual attain of organizational and personal goals (Swanson, 1995). HRD is the integrated use of training and development, career development and organizational development to improve individual and organizational effectiveness (Mc Lagan, 1989). Moreover, human resource development is planned and continuous process of helping employees to become better at their tasks, knowledge and experiences through training, education and development programs (Desimon, et., al., 2002).

Training and development have greater roles in developing human resources in the country and contribute significantly to economic success. Organizations have human and nonhuman resources in order to achieve their specific objectives. So people are the most significant resources of any organization. In most cases, there may be gap between employee knowledge and skill and the job demand. The gap must be filled and people should be kept unrest with the growing technologies and their efforts, attitudes and skills (Lewin and Janet, 1999).

However, ineffective HRD practice can bring many problems, such as reduced employees' enthusiastic to learn and apply new skills, decreased employee productivity, low morale, and higher employee turnover (Fiona and Alan, 2005). Developing an effective HRD practice is a difficult task since it demands to look into the needs of the employees and ensure that the practices are aligned with both organization and employees need.
Therefore, problems in HRD systems arise when the training and development practices fail to accommodate employees' needs. So if an organization wants to entrance employees' satisfaction and retain its' employees, it should concern with improving the skills, knowledge, attitudes and behavior of employees in organization settings for the benefit of both employees and the organization.

However, from personal observation and work experience of the researchers, development and training programs provided in the selected area faced different problems. For example some employees complain that the training offered to employees are not directly related to daily tasks, sometimes the time given to the training was not proportional to the contents of the training and etc. Moreover, a number of researchers have been conducted so far in search of solutions for problems in education sector in Ethiopia. The problems are related to human resource management and development of which senior secondary schools are pearly addressed. To the knowledge of researchers, no study was conducted to investigate the practice and challenges of human resource development in secondary schools of Hadiya zone.

Therefore, the researchers initiated to assess the practices and challenges of HRD in secondary schools of Hadiya zone of southern nations, nationalities and peoples region (SNNPR).

\section{Statement of the Problem}

Organizations can rarely secure people who are at the time of employment, total masters of their unique requirements. In most cases, there may be gap between employees' knowledge, skills and attitude and what the job demand. The gap must be filled through human resource development programs.

As a result, personnel training, development and education are the major ways that institutions attempt to maintain the competency levels of their human resources and increase their adaptability to changing organization demand. Thus employees face the need to constantly upgrade their skills and develop an attitude that permits them to adapt change. Machineries, materials and money, cannot be manipulated and property utilized without skilled and trained manpower, person's knowledge and skill do not exist forever unless it is refreshed and developed through learning and training (Tamirat, 2010).

There are different factors that affect the training and development practices of organization. Among factors that hinder the practice of training and development, economical, social, technological and governmental; changes. Training and development practice can be influenced by perception of the individuals on method of delivery, content of the training, selection and evaluation of the program (Laird, 1985).

The current education and training policy (ETP) of the country under its educational management part indicated the importance of employee's development that management of teachers and other personnel principles including professional growth with overall rights and duties added to 
this criterion for professional development of employees will get continuous education and training.

The efforts being made for the delivery of efficient and effective human resource development programs were encouraging to maximize the productivity of employees and to improve their performance, but behavior and performance do not always reflect the extent of training and delivered. Generally, absence of well-established training and development policy, lack of adequate budget, inadequate needs assessment, inappropriate training and development objectives, trying out dated training and development methods, lack of close supervision and follow up are some of the major problems of the organizations in Ethiopia (Tamirat, 2010). Moreover, as indicated in the introduction part, development program offered at the selected area have been observed through work experience of the researcher to have different problems regarding the issue. For example, it has been observed that some employees were not efficiently performing their daily tasks, priority would not be given to the human resource development and the contents were not proportional. No study has been made to gear the training to a needed direction. This indicates that there is an important research gap to be filled. Hence, this study is designed to assess the practices and challenges of human resource development in secondary schools of Hadiya zone and the study is expected to answer the following basic questions.

1. What are the current practices in human resource development activities among schools, woredas, and zone education department?

2. To what extent needs assessment is made by selected secondary school in conducting human resource development in Hadiya Zone?

3. What are the challenges encountered in the implementation of human resource development and training in selected secondary schools of Hadiya Zone?

\section{Objectives of the Study}

\subsection{General Objective}

To investigate the practices and challenges of human resource development in secondary schools in Hadiya Zone, SNNPR.

\subsection{Specific Objectives}

The study has the following specific objectives:

1. To assess the current practices in human resource development activities among schools, woredas, and zone education department.

2. To examine the extent of needs assessments made by the selected secondary schools in providing human resource development programs.

3. To find out the challenges encountered in the effective implementation of human resource development and provide possible recommendation for wards the issue, for the schools organizations.

\section{Research Design and Method}

The main purpose of the research design is to describe the practices and challenges of human resource development of government secondary schools in Hadiya Zone. The research design adopted in this study was descriptive survey study design, which is a common characteristic shared by qualitative and quantitative research (Cohen, 2007). The purpose of descriptive is to describe some aspects of phenomena.

Descriptive survey research design gather a data at a particular point in time with the intention of describing the nature of existing conditions, or determining the relationships that exists between specific events (Abiy (2009).

The study employed quantitative and qualitative method of mixed research type concurrently. Quantitative research used for summarizing large amount of data and reaching generalization based on statistical estimation whereas qualitative research used to take the story from the participant viewpoints providing the rich, descriptive data that sets quantitative results in to their human context (Cohen, 2007). These methods used because the strength of both quantitative and qualitative research can provide the best understanding.

\subsection{Data Sources}

The researcher used both primary and secondary source of data. Primary sources of data used in this study were teachers, principals and supervisors and secondary source was documentary analysis of the sample schools.

\subsubsection{Primary Sources}

Quantitative data were collected by using a structured questionnaires having close ended from teachers, vice principals, principals and supervisors. Qualitative data was collected by using key informants from experts and woreda education office heads. They are selected for interview because they have sufficient information and experience on the issue under the study

\subsubsection{Secondary Sources}

Secondary data used to compare it with the primary data and strengthen the data from primary sources. Hence, secondary sources of data obtained from document analysis of sample school of teacher appraisal performance results and woreda education offices' statistical data reports.

\subsection{Sample Size and Sampling Techniques}

The aim of this study is to find out the practices and challenges of human resource development in government secondary schools in Hadiya zone. To achieve this purpose, eight woredas were randomly selected from eleven woredas in hadiya zone. In selected eight woredas there are 22 Secondary Schools. In the first place from the twenty two secondary schools $8(36.36 \%)$ are selected by simple random sampling techniques, in order to decrease the problem of sampling bias. Totally in the above mentioned secondary 
schools there are 300 teachers 21 school principals and 3 supervisors.

Thus from 8 secondary schools $100(33.33 \%)$ teachers selected by systematic random sampling, 21 (100\%) principals and $3(100 \%)$ supervisors were selected through purposive sampling techniques because their role is directly related with the human resource development. In using this sampling technique responsibility from different level of management status, sex and experiences fairly included. Then the total number of respondents were 124 (38.3\%). In particular, the variance between individual results within the sample is a good indicator of variance in the overall population which made it relatively easy to estimate the accuracy of results.

Table 1. Total and Sample Population of Teachers in the Study.

\begin{tabular}{|c|c|c|c|c|c|c|c|}
\hline \multirow{2}{*}{ No } & \multirow{2}{*}{ Woreda } & \multirow{2}{*}{$\begin{array}{l}\text { The Sample } \\
\text { Secondary Schools }\end{array}$} & \multicolumn{3}{|c|}{ Total Population of Teachers } & \multirow{2}{*}{$\begin{array}{l}\text { Sample } \\
\text { Population }\end{array}$} & \multirow{2}{*}{$\%$} \\
\hline & & & $\mathbf{M}$ & $\mathbf{F}$ & $\mathbf{T}$ & & \\
\hline 1 & Soro & Kosha & 29 & 6 & 35 & 12 & 34.3 \\
\hline 2 & Gibe & Homacho & 24 & 5 & 29 & 9 & 31.0 \\
\hline 3 & Duna & Ansho & 28 & 7 & 35 & 12 & 34.3 \\
\hline 4 & Misha & Morsuto & 25 & 9 & 34 & 11 & 32.4 \\
\hline 5 & Gombora & Bushana & 20 & 4 & 24 & 8 & 33.3 \\
\hline 6 & Shashogo & Bonosha & 19 & 6 & 25 & 8 & 32.0 \\
\hline 7 & East Badawacho & Korga & 18 & 8 & 26 & 10 & 38.5 \\
\hline 8 & Hossana Town Administration & Yekatit 25/67 & 75 & 17 & 92 & 30 & 32.6 \\
\hline Total & & & 238 & 62 & 300 & 100 & 33.3 \\
\hline
\end{tabular}

Table 2. Population, Sample Size and Sampling Technique.

\begin{tabular}{|c|c|c|c|c|c|c|c|c|c|c|}
\hline \multirow{2}{*}{ No } & \multirow{2}{*}{ Respondent } & \multicolumn{3}{|c|}{ Population } & \multicolumn{3}{|c|}{ Sample Size } & \multirow{2}{*}{$\%$} & \multirow{2}{*}{$\begin{array}{l}\text { Sampling } \\
\text { Technique }\end{array}$} & \multirow{2}{*}{ Reasons } \\
\hline & & $\mathbf{M}$ & $\mathbf{F}$ & $\mathbf{T}$ & $\mathbf{M}$ & $\mathbf{F}$ & $\mathbf{T}$ & & & \\
\hline 1 & Teachers & 238 & 62 & 300 & 69 & 31 & 100 & 33 & Random & To give equal chances \\
\hline 2 & Principals & 20 & 1 & 21 & 20 & 1 & 21 & 100 & available & Their number is manageable \\
\hline 3 & Supervisors & 3 & - & 3 & 3 & - & 3 & 100 & available & Their number is manageable \\
\hline 4 & Woredas education office head & 8 & - & 8 & 3 & - & 3 & 37.5 & Purposive & To get dependable information \\
\hline 5 & General quality education head & 8 & - & 8 & 3 & - & 3 & 37.5 & Purposive & To get dependable information \\
\hline 6 & $\begin{array}{l}\text { Teachers principal and } \\
\text { supervisors training office }\end{array}$ & 8 & - & 8 & 3 & - & 3 & 37.5 & Purposive & To get dependable information \\
\hline 7 & Zone Education experts & 4 & 1 & 5 & 2 & 1 & 3 & 60 & Purposive & To get dependable information \\
\hline Total & & 289 & 64 & 353 & 103 & 33 & 136 & 38.5 & & \\
\hline
\end{tabular}

\subsection{Methods of Data Collection}

In order to obtain information pertaining to the subject in the study, different instruments like questionnaires and semistructured interviews were designed and used. These multi method approach minimizes the chance of inconsistent findings that are attributable to similarities of methods indicated (Lewin and Janet, 1999).

\subsubsection{Questionnaires}

Both open and close ended questionnaires were distributed to systematically selected respondents 21 principals, 3 supervisors and 100 teachers. Generally, the questionnaires are made to have two parts with all items consisting of both close and open ended types. The first part was in both cases designed to seek personal information of respondents while the second part assesses possible challenges and practices of human resource development. The questionnaires are prepared in English for all respondents.

\subsubsection{Interview}

The interview conducted to collect supplementary opinion with Woreda education office and zone education department experts and heads. They are selected for interview because they have sufficient information and experience on the issue under the study.

In addition, the interview permits greater depth of response which is not possible through any other means (James and Rodney, 1991).

\subsubsection{Document Analysis}

Document analysis was used to collect relevant data for the study, for example, annual statistical abstracts and other documents produced by REB, ZED and WEOs were reviewed and analyzed to collect secondary information's about human resource development practices of the secondary schools the study.

\subsection{Pilot Study}

Before the main questionnaire is administered the questions tested through pilot study. The pilot test conducted in two secondary schools of the zone namely Heto and Fonko secondary schools which are not among the sampled schools. From those schools fourteen teachers, two principals, two vice principals and two supervisors, totaling twenty participants are included in the pilot test.

The purpose of the pilot test is to identify and check whether the quaternaries are valid and reliable. Based on the responses given on the pilot test, items which lacked clarity were rephrased; poor and vague items were also discarded. Moreover, after the questionnaires were filled and returned the reliability and validity of the items were measured by the help of SPSS version 20. The obtained test result was 0.851 . 
Then as the result indicated it was a good indicator of the internal consistency of the items. Finally, this the refined questionnaire were distributed to the respondents of the study.

\subsection{Procedure of Data Collection}

After review of the related literature, all instruments developed by the researcher, then in order to establish validity the proposed questioners are tried in working school of the researcher. After they tried out, each items and instruments carefully examined, improved, and restructured and made for final data collection. Next, improved questionnaires distributed to be filled by the respondents.

\subsection{Methods of Data Analysis}

The data gathered through primary and secondary method can be analyzed by using both mixed data analysis methods, that is quantitative and qualitative ways because a mixed approaches can provide a fuller description and more complete explanation of the phenomenon being studied by providing more than one perspective on it and the result from one method can help to develop or inform the other method. Quantitative way of presenting the data collected in the course of questionnaires using SPSS version 20.0 statistical data processer software application and descriptive statistics such as table and numbers with percentage as well as mean and standard deviation. Qualitative method of data analysis also employed for feedbacks obtained through interview, open ended questionnaires, and secondary data sources and the data collected analyzed and interpreted in the form of narration.

\subsection{Ethical Consideration}

Attempts made to formulate the research process professional and ethical. To this end, the researcher tried to clearly inform to the respondents about the purpose of the study that it is purely for academic reason. The researcher introduced its purpose in the introduction section of the questionnaire and interview guide to the respondents, and confirms that subjects, confidentiality would be ensured. In general, the researcher did not try to personalize any of the reaction of the respondents during data presentations, analysis and interpretations. Besides, all the resources used for this research are appropriately acknowledged. The right to maintain privacy guaranteed anonymity; guaranteed confidentiality; and avoiding harm these all were accordingly applied in this study.

\section{Discussions and Findings}

\subsection{Characteristics of the Respondents}

According to the responses of respondents, their background information was assessed in terms of sex, age, position, work experience and educational status. The main sources of information were woreda and zone education officials, supervisors, principals, and teachers in secondary schools of Hadiya Zone. A total of 124 questionnaires were prepared and distributed to teachers, principals and supervisors. Accordingly, out of the total 124 questionnaires distributed to the respondents $(100 \%)$ were filled out properly and returned. In addition to questionnaire, to raise the quality of data and to supplement the data that been collected from questionnaires, interviews were also conducted with 8 woreda and zone education officials. This has also been checked through document analysis.

As it can be observed from Table 3 of item one, 69 (69\%) of the respondents, $23(95.8 \%)$ of instructional leaders (main principals, vice principals) and all of the supervisors and heads of the WEOs were males, while the remaining 31 (31\%) of the teachers and $1(4.2 \%)$ of the principals were female respondents. This, in turn shows that the participation of females in school and educational leadership was still limited.

Table 3. Characteristics of the Respondents.

\begin{tabular}{|c|c|c|c|c|c|c|c|c|c|c|}
\hline \multirow{3}{*}{ No } & \multirow{3}{*}{ Items } & \multirow{3}{*}{ Category of Items } & \multicolumn{8}{|c|}{ Respondents } \\
\hline & & & \multicolumn{2}{|c|}{ Teachers } & \multicolumn{2}{|c|}{ Principals and Supervisors } & \multicolumn{2}{|c|}{ WEO experts and heads } & \multicolumn{2}{|c|}{ Total } \\
\hline & & & No & $\%$ & No & $\%$ & No & $\%$ & No & $\%$ \\
\hline \multirow{3}{*}{1} & \multirow{3}{*}{ Sex } & Male & 69 & 69 & 23 & 95.8 & 9 & 100 & 101 & 75.9 \\
\hline & & Female & 31 & 31 & 1 & 4.2 & - & - & 32 & 24.1 \\
\hline & & Total & 100 & 100 & 24 & 100 & 9 & 100 & 133 & 100 \\
\hline \multirow{6}{*}{2} & \multirow{6}{*}{ Age in Years } & $18-25$ & 23 & 23 & - & - & - & - & 23 & 17.3 \\
\hline & & $26-30$ & 22 & 22 & 6 & 25 & 3 & 33.3 & 31 & 23.3 \\
\hline & & $31-35$ & 26 & 26 & 13 & 54.2 & 1 & 11.1 & 40 & 30.1 \\
\hline & & $36-40$ & 21 & 21 & 3 & 12.5 & 4 & 44.4 & 28 & 21 \\
\hline & & Above 40 & 8 & 8 & 2 & 8.3 & 1 & 11.1 & 11 & 8.3 \\
\hline & & Total & 100 & 100 & 24 & 100 & 9 & 100 & 133 & 100 \\
\hline \multirow{4}{*}{3} & \multirow{4}{*}{$\begin{array}{l}\text { Qualification or } \\
\text { level of Education }\end{array}$} & Diploma & 7 & 7 & - & - & - & - & 7 & 5.3 \\
\hline & & $\mathrm{BSc} / \mathrm{BA}$ & 78 & 78 & 18 & 75 & 7 & 77.8 & 103 & 77.4 \\
\hline & & $\mathrm{MSc} / \mathrm{MA}$ & 15 & 15 & 6 & 25 & 2 & 22.2 & 23 & 17.3 \\
\hline & & Total & 100 & 100 & 24 & 100 & 9 & 100 & 133 & 100 \\
\hline \multirow{6}{*}{4} & \multirow{6}{*}{ Work experience } & $1-5$ Years & 11 & 11 & - & - & - & - & 11 & 8.3 \\
\hline & & 6-10 Years & 9 & 9 & 4 & 16.7 & - & - & 13 & 9.8 \\
\hline & & 11-15 Years & 31 & 31 & 11 & 16.7 & 3 & 33.3 & 45 & 33.8 \\
\hline & & $16-20$ Years & 41 & 41 & 7 & 29.2 & 2 & 22.2 & 50 & 37.6 \\
\hline & & Above 20 Years & 8 & 8 & 2 & 8.3 & 4 & 44.5 & 14 & 10.5 \\
\hline & & Total & 100 & 100 & 24 & 100 & 9 & 100 & 133 & 100 \\
\hline
\end{tabular}


According to these data, almost $75.9 \%$ of the respondents were males and only $24.1 \%$ were females in all positions. This show that the females' participation, as compared to their male counter parts, were very low both in the teaching and leadership position at secondary schools level. Thus, the responses of the subject in the study have represented predominantly males' idea.

With regard to the age distribution, the majority $53.4 \%$ of the respondents were in the age of group of between 26-30 and 31-35 years.

Very few respondents were within the age group of 40 and above years. While there were $17.3 \%$ of the total respondents below in the age between $18-25$ years. Therefore, this figure indicates that the majority of the respondents are matured enough to provide reliable information with regard to the issue under study.

With regards to educational qualification, the majority $77.4 \%$ of respondents were bachelor degree holders, While $17.3 \%$ of respondents were second degree holders and very few only $5.3 \%$ were diploma holders. This shows that most of them have adequate qualifications in relation to the jobs. However, the existence of diploma in the teaching staff indicates that there is a need for upgrading them in the future.

Concerning the total year of work experiences, majority $82 \%$ of the respondents, had served for more than 10 years in the office or in the education sector. About $9.8 \%$ of the respondents served for 6-10 years. However, only $8.3 \%$ was grouped in 1-5 years range. This information suggested that most of the employees had long year services and they could give enough information. Finally combination of different age, education level and service of participants in the study area were found to be satisfactory to get reliable data for the study.

\subsection{Presentation, Analysis and Interpretation of Data}

Now a day, many organizations realized the significance and crucial role of training and development of their human resources for their survival. Therefore, they gave emphasis for this issue because through training and development important skills such as problem solving, communication and team building are developed.

Likewise, training and development increases the motivation and commitment of employees to achieve organizational goals. So, education sectors also organized training and development programs for their employees based on such idea. This part of the study served as a background of the main section of the study tries to investigate whether development programs had been conducted in secondary schools or not. An attempt was also made to identify those who designed or organize these programs, the type and contents of the programs and the level of participation.

\subsubsection{Analysis of Data Obtained on Contents, Arrangement and Types of HRDPs}

To identify contents (topics), arrangement and type of human resource development programs provided by secondary schools in Hadiya zone, 9 items were presented in the questionnaire to be responded by respondents. The responses are depicted in Tables 4 and 5.

As it was shown in Table 4 in item one, 104 (83.9\%) of the respondents confirmed that short- term training and development programs were provided in their secondary schools. With regard to long- term training program, in item 2 , majority $102(82.2 \%)$ of the respondents replied that their offices didn't provide any long-term training. While the remaining $17.8 \%$ of the respondents responded that their secondary schools provided such programs.

The information obtained through interview with the principals, supervisors and woreda education officials and document analysis indicated that long-term programs were rarely provided to teachers and administrative staffs, when training opportunities were given as quotas by the MoE. From this we can conclude that long-term programs were rarely provided to employees when training opportunities were given as quotas by the MoE.

It can be observed in the Table 4 , in item 3, about 81 $(65.3 \%)$ of the respondents didn't attend any training and development programs at all. While the rest $34.7 \%$ of the respondents, attended the training programs provided in education departments at different levels. This implies that most of teachers and administrative staff did not attend any training and development programs.

Table 4. Arrangement and Types of HRTDP.

\begin{tabular}{|c|c|c|c|c|c|c|c|c|}
\hline \multirow{3}{*}{ No } & \multirow{3}{*}{ Items } & \multirow{3}{*}{ Responses } & \multicolumn{6}{|c|}{ Respondents } \\
\hline & & & \multicolumn{2}{|c|}{ Group I } & \multicolumn{2}{|c|}{ Group II } & \multicolumn{2}{|l|}{$\mathbf{T N}$} \\
\hline & & & $\mathbf{F}$ & $\%$ & $\mathbf{F}$ & $\%$ & $\mathbf{F}$ & $\%$ \\
\hline \multirow{3}{*}{1} & Did your school provide short-term training and & Yes & 83 & 83 & 21 & 87.5 & 104 & 83.9 \\
\hline & development programs for its teachers and & No & 17 & 17 & 3 & 12.5 & 20 & 16.1 \\
\hline & administrative staff? & Sub-total & 100 & 100 & 24 & 100 & 124 & 100 \\
\hline \multirow{4}{*}{2} & \multirow{4}{*}{$\begin{array}{l}\text { Did your school provide long-term training and } \\
\text { development programs for its teachers and } \\
\text { administrative staff }\end{array}$} & Yes & 9 & 9 & 1 & 4.2 & 10 & 8.1 \\
\hline & & To some extent & 4 & 4 & 8 & 33.3 & 12 & 9.7 \\
\hline & & No & 87 & 87 & 15 & 62.5 & 102 & 82.2 \\
\hline & & Sub-total & 100 & 100 & 24 & 100 & 124 & 100 \\
\hline \multirow{3}{*}{3} & Did you attend any training and development & Yes & 37 & 37 & 6 & 25 & 43 & 34.7 \\
\hline & program provided in your woreda education & No & 63 & 63 & 18 & 75 & 81 & 65.3 \\
\hline & office/Zone education department & Sub-total & 100 & 100 & 24 & 100 & 124 & 100 \\
\hline 4 & If your answer for item 3 is "yes" the program & WEO & 9 & 24.3 & 2 & 33.3 & 11 & 25.6 \\
\hline
\end{tabular}




\begin{tabular}{|c|c|c|c|c|c|c|c|c|}
\hline \multirow{3}{*}{ No } & \multirow{3}{*}{ Items } & \multirow{3}{*}{ Responses } & \multicolumn{6}{|c|}{ Respondents } \\
\hline & & & \multicolumn{2}{|c|}{ Group I } & \multicolumn{2}{|c|}{ Group II } & \multicolumn{2}{|l|}{$\mathbf{T N}$} \\
\hline & & & $\mathbf{F}$ & $\%$ & $\mathbf{F}$ & $\%$ & $\mathbf{F}$ & $\%$ \\
\hline \multirow{8}{*}{5} & \multirow[t]{5}{*}{ organized or designed by } & ZED & 8 & 21.6 & 1 & 16.7 & 9 & 20.9 \\
\hline & & $\mathrm{MoE}$ & 15 & 40.5 & 3 & 50 & 18 & 41.9 \\
\hline & & NGO’s & 5 & 13.5 & - & - & 5 & 11.6 \\
\hline & & Sub-total & 37 & 100 & 6 & 100 & 43 & 100 \\
\hline & & Short term work shop/seminar & 62 & 62 & 17 & 70.8 & 79 & 63.7 \\
\hline & \multirow{3}{*}{ The kind of HTD programs have you attended. } & In-service program & 27 & 27 & 5 & 20.8 & 32 & 25.8 \\
\hline & & Regular programs & 11 & 11 & 2 & 8.4 & 13 & 10.5 \\
\hline & & Sub-total & 100 & 100 & 24 & 100 & 124 & 100 \\
\hline
\end{tabular}

Note: Group I = Teachers, Group II = Principals and Supervisors, $\mathrm{F}=$ frequency, $\mathrm{TN}=$ Total Number and $\%=$ percentage.

As it is shown in Table 4 item 4, indicated about those who organized/ designed the training and development programs. Based on the responses; MoE, WEO, ZED, and others (NGO's) organized or designed the programs respectively. According to these responses majority (41.9\%) of those who attend the training and development programs participated in the programs organized by MoE. The second, third, fourth majority of the respondents attended the programs organized by ZED, WEO and NGO's. This indicates that MoE organized the programs in a large number.

Concerning the type of programs they had attended, Table 4, item 5 reported the following. Among those who attended training and development programs the data shows that most of respondents $(63.7 \%)$ attended short term seminar and work shop. Only $10.5 \%$ ) of the respondents attended regular program in higher education. Whereas, based on the data, $25.8 \%$ of them attended in-service programs. From the above information we can conclude that upgrading of teachers and administrative staff through learning in higher education institution found at lower level. Relatively greater emphasis was given to short- term programs. However, the education sector experts and heads during the interview asserted that the number of short-term programs was few and not adequate enough which allowed the participation of the majority of the employees and to equip them with efficient technical and human skills.

With regard to the inclusiveness of human resource training and development plans in the strategic plans of the school as indicated in Table 4, in item 4, the majority $82.3 \%$ replied that the strategic plans of their school did not incorporated for employees training and development programs. About $17.7 \%$ of the respondents believed that the strategic plans of their offices included their human resource training and development programs. The interview with the education sector heads and experts revealed that it was included to some extent in the strategic plans. The document analysis also confirmed this. The interview also confirmed that the current direction of the training and development programs mainly concentrated on such issues. It is possible to deduct that the education institutions also paid attention to gender and HIV/AIDS education.

Regarding the relationship of the contents towards their job, Table 5, item 2, about $85.5 \%$ of the respondents replied that the contents of the training programs had direct relationship with their jobs. But very few $8.1 \%$ expressed their disagreement. Since majority of the respondents attended the contents that are related teaching learning process. Therefore, it is possible to conclude that the contents had direct relationship with their jobs.

Table 5. Contents of TDPs, Job Assignment and Strategic Plans.

\begin{tabular}{|c|c|c|c|c|c|c|c|c|}
\hline \multirow{3}{*}{ No } & \multirow{3}{*}{ Items } & \multirow{3}{*}{ Responses } & \multicolumn{6}{|c|}{ Respondents } \\
\hline & & & \multicolumn{2}{|c|}{ Group I } & \multicolumn{2}{|c|}{ Group II } & \multicolumn{2}{|l|}{$\mathbf{T N}$} \\
\hline & & & $\mathbf{F}$ & $\%$ & $\mathbf{F}$ & $\%$ & $\mathbf{F}$ & $\%$ \\
\hline \multirow{3}{*}{1} & \multirow{3}{*}{ The strategic plan incorporated in the TDP plan } & Yes & 83 & 83 & 19 & 79.2 & 102 & 82.3 \\
\hline & & No & 17 & 17 & 5 & 20.8 & 22 & 17.7 \\
\hline & & Sub-total & 100 & 100 & 24 & 100 & 124 & 100 \\
\hline \multirow{4}{*}{2} & \multirow{4}{*}{$\begin{array}{l}\text { The training and development program you have } \\
\text { attended directly related to your job }\end{array}$} & Yes & 90 & 90 & 16 & 66.7 & 106 & 85.5 \\
\hline & & To some extent & 3 & 3 & 5 & 20.8 & 8 & 6.4 \\
\hline & & No & 7 & 7 & 3 & 12.5 & 10 & 8.1 \\
\hline & & Sub-total & 100 & 100 & 24 & 100 & 124 & 100 \\
\hline \multirow{3}{*}{3} & \multirow{3}{*}{$\begin{array}{l}\text { You got proper placement and benefits in } \\
\text { association to the TDP }\end{array}$} & Yes & 79 & 79 & 20 & 83.3 & 99 & 79.8 \\
\hline & & No & 21 & 21 & 4 & 16.7 & 25 & 20.2 \\
\hline & & Sub-total & 100 & 100 & 24 & 100 & 124 & 100 \\
\hline \multirow{5}{*}{4} & \multirow{5}{*}{$\begin{array}{l}\text { The contents (topics) of the training and } \\
\text { development programs were }\end{array}$} & Continuous professional development & 47 & 47 & 14 & 58.3 & 61 & 49.2 \\
\hline & & Active learning method & 32 & 32 & - & - & 32 & 25.8 \\
\hline & & Gender and HIV/ ADS education & 17 & 17 & 4 & 16.7 & 21 & 16.9 \\
\hline & & Computer training & 4 & 4 & 6 & 25 & 10 & 8.1 \\
\hline & & Sub-total & 100 & 100 & 24 & 100 & 124 & 100 \\
\hline
\end{tabular}

Note: Group I = Teachers, Group II = Principals and Supervisors, F = frequency, $\mathrm{TN}=$ Total Number and $\%=$ percentage.

As it is observed in the Table 5 in item 3, respondents was asked if they had attended and completed long-term training programs and got the proper placements or benefits. The majority of them (79.8\%) responded that they had got the proper 
position and placement. From which it is possible to conclude that employees got the advantages due to their experience.

Concerning the contents of the programs, Table 5, item 4 presented the following information. Regardless of the frequency and duration of the programs, the contents were ranged according to the number of the participant's responses. The contents of continuous professional development, active learning methods, gender and HIV education, and computer training ranked highest to least respectively. However, no one confirmed that special need education was given as content of the program.

From the above information it is possible to deduct that main emphasis was given to teaching learning activities than others and no emphasis was given to special needs education.

\subsubsection{Analysis of Data Obtained on Training and Development Needs Assessment}

As it was discussed in the review of the literature, conducting training development needs assessment is the initial and important step in human resource training and development practices. In a systematic model of training needs assessment, analysis is concerned with identifying the work, which is not performed and the standards of training and development programs that give a solution. Moreover, conducting the training needs assessment in this way requires systematic analysis and specifies training. Concerning this, respondents were asked whether their schools/organization conduct HR training and development needs assessment for its employees or not.

Table 6. Identification of HR Training and Development Needs.

\begin{tabular}{|c|c|c|c|c|c|c|c|c|c|c|}
\hline \multirow{3}{*}{ No } & \multirow{3}{*}{ Items } & \multirow{3}{*}{ Respondents } & \multicolumn{8}{|c|}{ Level of Agreement } \\
\hline & & & \multicolumn{2}{|c|}{ A } & \multicolumn{2}{|l|}{$\mathbf{S}$} & \multicolumn{2}{|l|}{$\mathbf{N}$} & \multicolumn{2}{|l|}{$\mathbf{T N}$} \\
\hline & & & $\mathbf{F}$ & $\%$ & $\mathbf{F}$ & $\%$ & $\mathbf{F}$ & $\%$ & $\mathbf{F}$ & $\%$ \\
\hline \multirow{3}{*}{1} & \multirow{3}{*}{$\begin{array}{l}\text { My school conducted human resource and } \\
\text { development needs assessment }\end{array}$} & Group I & 29 & 29 & 31 & 31 & 40 & 40 & 100 & 100 \\
\hline & & Group II & 5 & 20.8 & 8 & 33.3 & 11 & 45.8 & 24 & 100 \\
\hline & & Sub-total & 34 & 27.4 & 39 & 31.5 & 51 & 41.1 & 124 & 100 \\
\hline \multirow{3}{*}{2} & \multirow{3}{*}{$\begin{array}{l}\text { Each individual identifies training and } \\
\text { development needs }\end{array}$} & Group I & - & - & 24 & 24 & 76 & 76 & 100 & 100 \\
\hline & & Group II & 1 & 4.2 & 5 & 20.8 & 18 & 75 & 24 & 100 \\
\hline & & Sub-total & 1 & 0.8 & 29 & 23.4 & 94 & 75.8 & 124 & 100 \\
\hline \multirow{3}{*}{3} & \multirow{3}{*}{$\begin{array}{l}\text { Top level leaders determined TD needs of } \\
\text { employees }\end{array}$} & Group I & 15 & 15 & 21 & 21 & 64 & 64 & 100 & 100 \\
\hline & & Group II & 3 & 12.5 & 5 & 20.8 & 16 & 66.7 & 24 & 100 \\
\hline & & Sub-total & 18 & 14.5 & 26 & 21.0 & 80 & 64.5 & 124 & 100 \\
\hline \multirow{3}{*}{4} & \multirow{3}{*}{$\begin{array}{l}\text { TD needs assessment had been identified } \\
\text { through analysis of the plan and objectives }\end{array}$} & Group I & 30 & 30 & 33 & 33 & 37 & 37 & 100 & 100 \\
\hline & & Group II & 4 & 16.7 & 7 & 29.2 & 13 & 54.1 & 24 & 100 \\
\hline & & Sub-total & 34 & 27.4 & 40 & 32.3 & 50 & 40.3 & 124 & 100 \\
\hline \multirow{3}{*}{5} & \multirow{3}{*}{$\begin{array}{l}\text { TD needs assessment had been identified } \\
\text { through analysis of the task }\end{array}$} & Group I & 26 & 26 & 21 & 21 & 53 & 53 & 100 & 100 \\
\hline & & Group II & 6 & 25 & 5 & 20.8 & 13 & 54.2 & 24 & 100 \\
\hline & & Sub-total & 32 & 25.8 & 26 & 21 & 66 & 53.2 & 124 & 100 \\
\hline
\end{tabular}

Note: Group I = Teachers, Group II = Principals and Supervisors, $\mathrm{A}=$ Always, $\mathrm{S}=$ Sometimes, $\mathrm{N}=\mathrm{Never}$, and TN $=$ Total Number.

As shown in Table 6 in item 1, respondents were asked whether their respective secondary schools/education departments conducted HR training and development needs assessment for their employees (educational leaders, teachers and co-workers). About $51(41.1 \%)$ of the respondents replied that training and development needs were rarely or never conducted.

About $34(27.4 \%)$ of the respondents viewed that the secondary schools "always or usually conducted" training and development needs assessment. On the other hand, 39 $(31.5 \%)$ of respondents viewed that the offices "sometimes conducted" training and development. The information gathered through interview with TDP officers and heads were also confirmed that there was no sufficient needs assessment systematically conducted. From this we can conclude that the secondary schools/ education departments didn't well organized HR training and development needs assessment for their employees and school leaders.

With regard to the role of individual employees in identifying their training and development needs Table 6, item 2 indicated that majority $94(75.8 \%)$ of the respondents viewed that each individual "never" identified his/her own training and development needs. Moreover, 29 (23.4\%) of the respondents viewed that each individual sometimes identified his/her own training and development needs. On the other hand, only $1(0.8 \%)$ of the respondents viewed that each individual "always identify" his/her training and development needs. From the data obtained, it can be concluded that in the selected secondary schools, individuals didn't identify their own training and development needs.

The information gathered through interview with the training and development experts, and officials also reveals that individuals didn't identify their own needs in their respective schools.

As indicated in Table 6 in general information part of item 3, MOE and other organizations designed most of the training and development programs. Perhaps these organizations conducted the programs without considering and collecting the true needs of employees in the schools/ education sector. As it had also indicated in Table 6, numerous short-term programs were designed at national and conducted all over the country simultaneously. The information gathered through interview also supported this assumption.

As it can be observed in Table 6 in items 2-3 respondents were asked to respond who identified training and development needs for the teachers and administrative staffs. Table 5 item 3 shows the top level educational leaders/officials in identifying the training and development 
needs of individuals and the schools.

Accordingly, about 80 (64.5\%) the respondents replied that the top level educational leaders/officials, never identified the training and development needs of individuals and the school. While, 18 (14.5\%) of the respondents responded that it always identified the training and development needs of individuals and the school. About $26(21.0 \%)$ of the respondents replied sometimes. Based on the above information, it is possible to conclude that in the selected study area the top level educational leaders/officials mostly didn't identify the training and development needs of individuals and the school. According to the information gathered through interviews, the top level educational leaders/officials didn't identify the training needs of individual employees and the organization. From the above information, it is possible to conclude that top-level managers made insufficient efforts to identify training and development needs of individuals and the organization systematically. Perhaps there were many factors like paying less attention, concentration on routine works, negligence, personal attitudes towards the importance of the issue, shortage of budget and low commitment limited their efforts.

As it is shown in Table 6, item 4 the techniques used to identify training and development needs are clearly indicated. Concerning the identification of needs through organizational analysis Table 6 item 4 shows that about $50(40.3 \%)$ of the respondents confirmed that organizational analysis was never conducted. About 34 (27.4\%) of the respondents confirmed that their respective schools "always" conducted organizational analysis to identify training and development needs. On the other hand, $40(32.3 \%)$ of the respondents replied that their schools sometimes conducted organizational analysis.

From the above information it is possible to conclude that there was no adequate effort made in conducting organizational analysis in the identification of training and development needs. The result of this item is in contradiction with the efforts made during the preparation of the strategic plans of the schools. However, during the preparation of the strategic plans, the main focus was on the analysis of internal and external environments of their respective school.

Organizational analysis is one of the ways to diagnose training needs. However, in the education departments of the research area it was not done for training and development purposes (Mathis and Jackson, 1997).

As it was observed in the Table 6 item 5, with regard to the practice of task analysis, the majority $66(53.2 \%)$ of the respondents viewed that their schools never conducted task analysis for training and development needs assessment. While $32(25.8 \%)$ of the respondents confirmed that their respective offices always conducted an analysis of individual tasks/jobs performed by each worker in the school. While 26 $(21.0 \%)$ respondents had replied that their schools conducted individual's task analysis sometimes.

Based on the information obtained from the above data it is possible to conclude that the secondary schools did not sufficiently conduct analysis of tasks/job performed by individuals to assess training and development needs in refute to the ideas suggested by (Gomez-Mejia and Cardy 1995) and (Getachew, 1998). The information collected through interviews reveals that there was no major effort done in analyzing tasks performed by individuals to conduct training and development needs assessment. They attributed the factors with the lack of interest and knowledge.

As it was observed in Table 7, items 1-5 focused on the factors that their schools/offices considered during TDP implementation. As it is shown in Table 7, item 1 indicated how often their schools considered the availability HR training facilities in prioritizing TDP. Accordingly, about $63(50.8 \%)$ of the respondents viewed that their respective schools considered the availability of facilities in prioritizing needs. On the other hand, $20(16.1 \%)$ respondents viewed it was never conducted. About 41 (33.1\%) of the respondents replied sometimes. Even though training and development needs were not identified in a systematic way, however, based on the above data it is possible to conclude that the availability of training facilities was considered in the departments in delivering training and development programs.

Table 7. Prioritizing Training and Development programs.

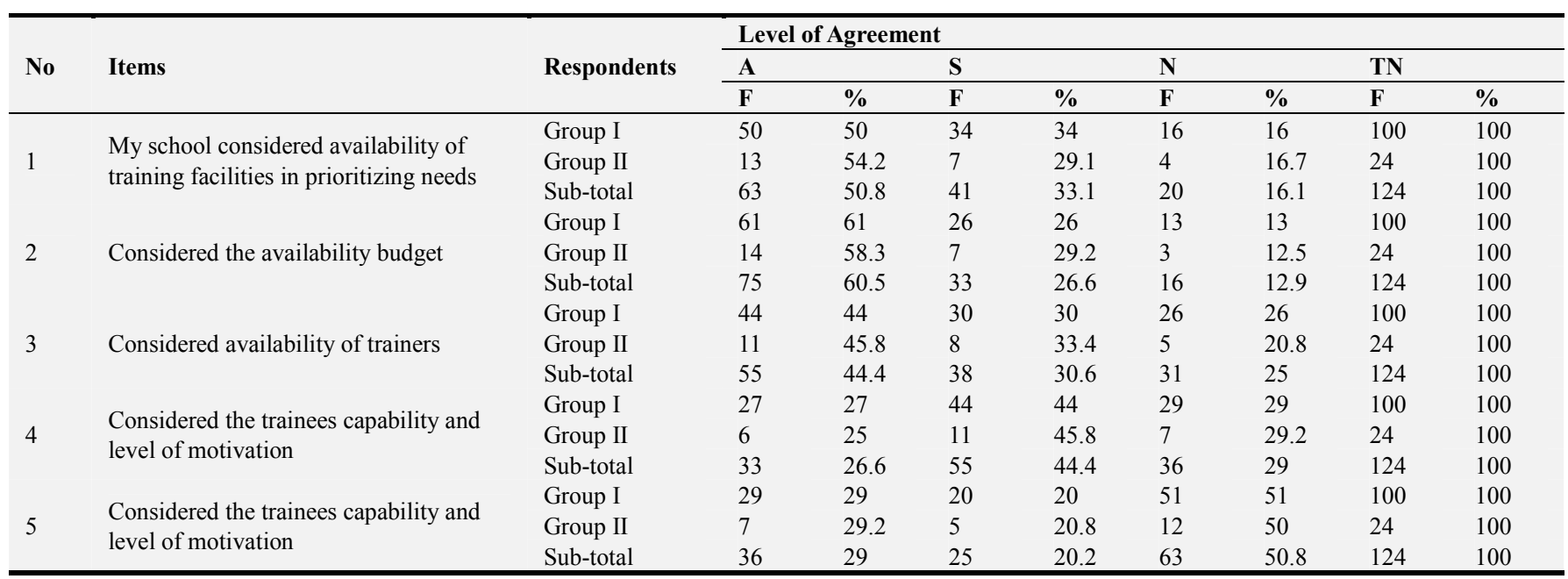

Note: Group I = Teachers, Group II = Principals and Supervisors, A = Always, $\mathrm{S}=$ Sometimes, $\mathrm{N}=$ Never, $\mathrm{TN}=$ Total Number and $\mathrm{F}=$ frequency. 
As it is shown in Table 7 item 2, with regard to considering the availability of budget as a factor in prioritizing needs, the majority about $75(60.5 \%)$ of the respondents confirmed that their respective schools/offices always considered the availability of budget as a factor in prioritizing needs. While about $33(26.6 \%)$ of the respondents viewed that their schools sometimes considered the availability of budget as a factor in prioritizing needs. About $16(12.9 \%)$ of the respondents replied that it was never considered.

Based on the above data it is possible to conclude that there is a positive effort in considering the availability of budget in prioritizing needs.

The information gathered through interviews with supervisors, principals and woreda education officers confirmed that greater emphasis was given towards the availability of budget in prioritizing needs. Based on the above data it is possible to conclude that there is a positive effort in considering the availability of budget in prioritizing needs.

As it is observed in Table 7 in item 3, in considering the availability of trainers as a factor in prioritizing needs, the majority $55(44.4 \%)$ of the respondents confirmed that it was considered, while, $38(30.6 \%)$ of the respondents replied sometimes considered. About 31 (25\%) of the respondents viewed it was never considered. Based on the above data it is possible to conclude that the schools/offices considered the availability of trainers in prioritizing needs.

As it is observed in Table 7, respondents were further asked to respond as method to item 4 whether their respective schools considered trainees capability and level of motivation as a factor in prioritizing needs. Accordingly, about 36 (29\%) of the respondents asserted that it was never considered. Majority, 55 (44.4\%) of the respondents replied that it was sometimes considered. While about $33(26.6 \%)$ of the respondents replied that it was always considered. The above information suggested that trainees' capability and level of motivation was not considered as a factor in prioritizing needs. However, according to the information gathered through interviews, it was sometimes considered in the secondary schools and woreda education offices. As it was observed in Table 7, item 5, in considering the appropriateness of training time as a factor in prioritizing needs, about $36(29 \%)$ of the respondents asserted that their respective offices always considered the appropriateness of training time in prioritizing needs. On the hand the majority $63(50.8 \%)$ of the respondents replied that never considered. While about $25(20.2 \%)$ of the respondents replied that it considered sometimes. Based on the above data we can conclude that the appropriateness of training time was not considered as a factor in prioritizing needs.

\subsubsection{Objectives and Focuses of HR Training and Development Programs}

With regard to this part, respondents' opinion to various question items were measured by summing (strongly disagree and disagree) as disagree, undecided as it was, (agree and strongly agree) as agree as indicated in Table 8, 9, 10 and 11 respectively. The question items were analyzed by calculating the frequency and percentage. Objectives are statements, which stated intended outcomes of training and development programs and should be prepared before the program launched.

As it can be seen in Table 8, item 1 majority $75(60.5 \%)$ of both groups of respondents agreed that in the training and development programs they have attended, objectives had been set before preparing and implementing the program. Conversely, $22(17 \%)$ the respondents expressed their disagreement. However, $27(21.8 \%)$ of the respondents were not sure about the issue. Moreover, the weighted mean score (3.48) indicates that the TDP objectives had been set before preparing and implementing the program in sample secondary schools.

Table 8. HR Training and Development Objectives and Focuses of the Programs.

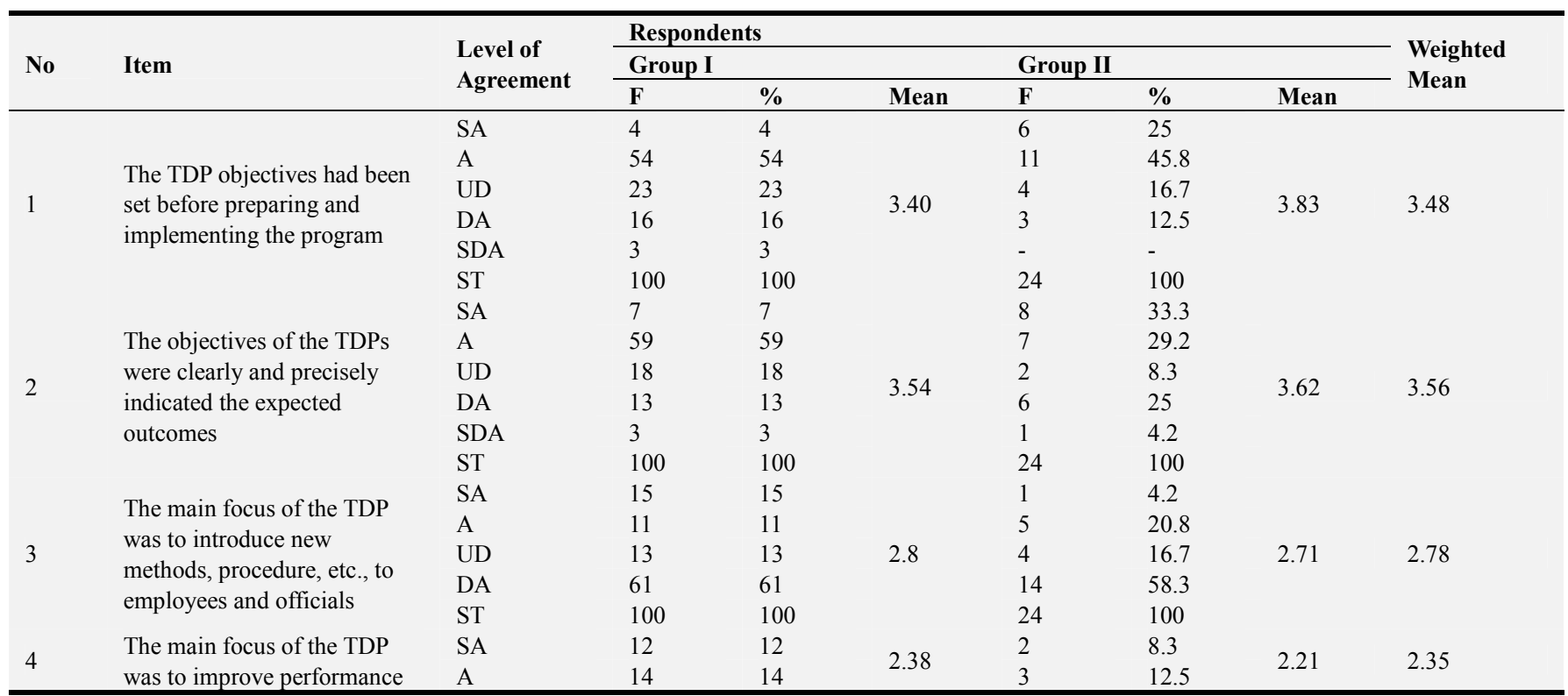




\begin{tabular}{|c|c|c|c|c|c|c|c|c|c|}
\hline \multirow{7}{*}{ No } & \multirow{3}{*}{ Item } & \multirow{3}{*}{$\begin{array}{l}\text { Level of } \\
\text { Agreement }\end{array}$} & \multicolumn{6}{|c|}{ Respondents } & \multirow{7}{*}{$\begin{array}{l}\text { Weighted } \\
\text { Mean }\end{array}$} \\
\hline & & & \multicolumn{3}{|c|}{ Group I } & \multicolumn{3}{|c|}{ Group II } & \\
\hline & & & F & $\%$ & Mean & $\mathbf{F}$ & $\%$ & Mean & \\
\hline & \multirow{4}{*}{$\begin{array}{l}\text { deficiency of employees and } \\
\text { educational leaders }\end{array}$} & UD & 12 & 12 & & - & - & & \\
\hline & & DA & 24 & 24 & & 12 & 50.0 & & \\
\hline & & SDA & 38 & 38 & & 7 & 29.2 & & \\
\hline & & ST & 100 & 100 & & 24 & 100 & & \\
\hline
\end{tabular}

Note: $\mathrm{SA}=$ strongly agree, $\mathrm{A}=$ Agree, $\mathrm{UD}=$ Undecided, $\mathrm{DA}=$ Disagree, $\mathrm{SDA}=$ strongly disagree, $\mathrm{ST}=$ Subtotal, Group $\mathrm{I}=$ Teachers, Group $\mathrm{II}=$ Principals and Supervisors, and $\mathrm{F}=$ frequency.

As it is in Table 8 , in item 2 with regard to the clarity and precision of the training and development programs' objectives in indicating the expected outcomes, the majority $81(65.3 \%)$ of both groups of respondents confirmed their agreement. However, about 23 (18.5\%) of the respondents expressed their disagreement. The rest 20 (18.5\%) were not sure about the issue.

Furthermore, the weighted mean score (3.56) shows that the extent of the precision and clarity of training and development objectives to indicate the expected outcomes of the programs were satisfactory in the rating scale. The information gathered through interviews also supported the above idea that emphasis was given to the methodology and contents rather than objectives.

Concerning the focus of the training and development programs delivered in the secondary schools those who had attended the programs expressed their opinion, in Table 7 item three, $32(25.8 \%)$ agreed that the main focus of the programs was to introduce new methods, procedures, etc. to employees and managers. About 75 (60.5\%) disagreed, while $17(13.7 \%)$ of both groups of respondents were not sure about the issue. From the above information responded by those who attended the programs, we can conclude that the main focus of the training was not to introduce new methods, procedures, etc., to employees and managers. Moreover, the weighted mean score (2.78) shows that the focus of the TDP to introduce new methods, procedure, etc., to employees and officials is below the medium in the rating scale.

Table 8 of item 4 depicts the responses whether the main focus of the program was to improve the job performance of the employees and officials. Accordingly, majority 81 $(65.3 \%)$ of the respondents disagrees that the main focus of the programs was to improve the job performance deficiency of the employees. Moreover, 31 (25\%) of respondents confirmed that the main focus of the program was to improve the job performance deficiency of the employees. On the other hand, about $12(9.7 \%)$ of the respondents commented nothing. Furthermore, the weighted mean score (2.35) shows that the extent of focus of the program to improve the job performance deficiency of the employees was not sufficient.

\subsubsection{Selection of Trainees, Trainers and Contents}

In the process of training and development, implementation involves the selection of the contents of the program, the selection of trainees, and qualified trainers, methods and facilities (Armstrong, 2001). For such purposes, the existence of clear selection criteria is an important aspect in human resource training and development practices.

Therefore the study tries, to assess the existence of the selection criteria for trainees and trainers, how training opportunities were offered to individuals, how trainers selected and who played a role in the selection of contents.

Table 9. Selection of Trainees.

\begin{tabular}{|c|c|c|c|c|c|c|c|c|c|}
\hline \multirow{3}{*}{ No } & \multirow{3}{*}{ Item } & \multirow{3}{*}{$\begin{array}{l}\text { Level of } \\
\text { Agreement }\end{array}$} & \multicolumn{6}{|c|}{ Respondents } & \multirow{3}{*}{$\begin{array}{l}\text { Weighted } \\
\text { Mean }\end{array}$} \\
\hline & & & \multicolumn{3}{|c|}{ Group I } & \multicolumn{3}{|c|}{ Group II } & \\
\hline & & & $\mathbf{F}$ & $\%$ & Mean & F & $\%$ & Mean & \\
\hline \multirow{6}{*}{1} & \multirow{6}{*}{$\begin{array}{l}\text { There were clear and } \\
\text { transparent selection criteria } \\
\text { for selecting trainees }\end{array}$} & SA & 3 & 3 & \multirow{6}{*}{2.73} & 1 & 4.2 & \multirow{6}{*}{2.79} & \multirow{6}{*}{2.74} \\
\hline & & A & 29 & 29 & & 7 & 29.2 & & \\
\hline & & UD & 6 & 6 & & 2 & 8.3 & & \\
\hline & & DA & 62 & 62 & & 14 & 58.3 & & \\
\hline & & SDA & - & - & & - & - & & \\
\hline & & ST & 100 & 100 & & 24 & 100 & & \\
\hline \multirow{6}{*}{2} & \multirow{6}{*}{$\begin{array}{l}\text { The selection criteria was } \\
\text { well communicated to all } \\
\text { members of my school }\end{array}$} & SA & - & - & \multirow{6}{*}{2.48} & - & - & \multirow{6}{*}{2.46} & \multirow{6}{*}{2.47} \\
\hline & & A & 17 & 17 & & 7 & 29.2 & & \\
\hline & & UD & 28 & 28 & & 2 & 8.3 & & \\
\hline & & DA & 41 & 41 & & 10 & 41.7 & & \\
\hline & & SDA & 14 & 14 & & 5 & 20.8 & & \\
\hline & & ST & 100 & 100 & & 24 & 100 & & \\
\hline \multirow{6}{*}{3} & \multirow{6}{*}{$\begin{array}{l}\text { TDP opportunities were } \\
\text { usually offered as incentive }\end{array}$} & SA & - & - & \multirow{6}{*}{2.49} & - & - & \multirow{6}{*}{2.13} & \multirow{6}{*}{2.42} \\
\hline & & A & 14 & 14 & & 4 & 16.7 & & \\
\hline & & UD & 28 & 28 & & 2 & 8.3 & & \\
\hline & & DA & 51 & 51 & & 11 & 45.8 & & \\
\hline & & SDA & 7 & 7 & & 7 & 29.2 & & \\
\hline & & ST & 100 & 100 & & 24 & 100 & & \\
\hline \multirow{3}{*}{4} & TDP opportunities offered to & A & 31 & 31 & \multirow{3}{*}{2.54} & 5 & 20.8 & \multirow{3}{*}{2.25} & \multirow{3}{*}{2.48} \\
\hline & appropriate individuals by & UD & 7 & 7 & & 2 & 8.3 & & \\
\hline & concerning organizational & DA & 57 & 57 & & 11 & 45.8 & & \\
\hline
\end{tabular}




\begin{tabular}{|c|c|c|c|c|c|c|c|c|c|}
\hline \multirow{3}{*}{ No } & \multirow{3}{*}{ Item } & \multirow{3}{*}{$\begin{array}{l}\text { Level of } \\
\text { Agreement }\end{array}$} & \multicolumn{6}{|c|}{ Respondents } & \multirow{5}{*}{$\begin{array}{l}\text { Weighted } \\
\text { Mean }\end{array}$} \\
\hline & & & \multicolumn{3}{|c|}{ Group I } & \multicolumn{3}{|c|}{ Group II } & \\
\hline & & & $\mathbf{F}$ & $\%$ & Mean & $\mathbf{F}$ & $\%$ & Mean & \\
\hline & goals & SDA & 5 & 5 & & 6 & 25 & & \\
\hline & & ST & 100 & 100 & & 24 & 100 & & \\
\hline \multirow{6}{*}{5} & \multirow{6}{*}{$\begin{array}{l}\text { TDP opportunities offered to } \\
\text { individuals based on personal } \\
\text { relationships }\end{array}$} & SA & - & - & \multirow{6}{*}{2.25} & - & - & \multirow{6}{*}{2.0} & \multirow{6}{*}{2.20} \\
\hline & & A & 18 & 18 & & 2 & 8.3 & & \\
\hline & & UD & 2 & 2 & & 1 & 4.2 & & \\
\hline & & DA & 67 & 67 & & 16 & 66.7 & & \\
\hline & & SDA & 13 & 13 & & 5 & 20.8 & & \\
\hline & & ST & 100 & 100 & & 24 & 100 & & \\
\hline \multirow{6}{*}{6} & \multirow{6}{*}{$\begin{array}{l}\text { Training and development } \\
\text { opportunities offered based } \\
\text { on trainees' interest }\end{array}$} & SA & 6 & 6 & \multirow{6}{*}{2.64} & 5 & 20.8 & \multirow{6}{*}{2.92} & \multirow{6}{*}{2.69} \\
\hline & & A & 11 & 11 & & 3 & 12.5 & & \\
\hline & & UD & 28 & 28 & & 2 & 8.3 & & \\
\hline & & DA & 51 & 51 & & 8 & 33.3 & & \\
\hline & & SDA & 4 & 4 & & 6 & 25 & & \\
\hline & & ST & 100 & 100 & & 24 & 100 & & \\
\hline
\end{tabular}

As it is shown in Table 9, item 1 respondent were asked to assert their opinion that their respective schools have clear and transparent criteria for selecting appropriate individual trainees. The majority $76(61.3 \%)$ of both group of respondents disagreed that their respective secondary schools had clear and transparent criteria for selecting appropriate individual trainees. On the other hand, 40 (32.3\%) of the respondents confirm their agreed by rating through strongly agree to agree. However, $8(6.4 \%)$ of the respondents were not sure about the issue. Furthermore, the weighted mean score (2.74) shows that the extent of formulating clear and transparent criteria for selecting appropriate individuals trainees was not sufficient.

Information obtained through interviews with experts and officials confirmed that there were no set criteria for teacher employees and administrative staff trainees for short or longterm training programs. Conventional method of selection was used towards the type of training, that sometimes they used the on-the-job training selection criteria set for the teacher trainees or used the criteria set by those who organized the trainings.

As it was observed in item 2 of Table 9, respondents were requested to assert their opinions whether the selection criteria were well communicated to all members of their offices. An overwhelming majority 70 (56.4\%) of both group of respondents indicated that the selection criteria were not well communicated to all members of their respective schools. However, few 24 (19.4\%) of the respondents agreed that the selection criteria were well communicated to all members of their respective offices. While, 30 (24.2\%) of the respondents viewed that they were not sure about the issue. In the above data it is indicated that most of the respondents disagreed that the selection criteria were communicated to all members of their schools. The reason why it is not communicated may be the inadequate practice of the selection criteria.

As it is observed in item 3, majority $76(61.3 \%)$ of both groups of respondents disagreed that training and development opportunities were offered to individuals as incentives by their respective schools. About 18 (14.5\%) of the respondents agreed that their respective schools offered training and development opportunities to individuals as incentives. While, $30(24.2 \%)$ of the respondents were not sure of the issue.

Moreover, the weighted mean score (2.42) indicates that training and development opportunities had not been sufficiently offered to individuals as incentives by their respective schools.

In item 4 also indicated that about 79 (63.7\%) of both groups of respondents confirm their disagreement by rating through disagree to strongly disagree in the rating scale. While, about $36(29 \%)$ of the respondents agreed that training and development opportunities were usually offered to appropriate individuals by considering organizational goals. While, about $9(7.3 \%)$ of the respondents were not sure about the issue. Moreover, the weighted mean score (2.48) reveals that the extent of this issue was below average in rating scale. As it was investigated from interviews, in most cases training and development opportunities were provided to individuals by considering organizational goals. However, there were problems towards the issue such as selecting few individual employees who had no direct contact with the job.

As it was indicated in Table 9, item 5 reported that whether training and development opportunities were usually offered to individuals who have good personal relationship with their immediate supervisors/leader. Regarding the issue, about 101 $(81.4 \%)$ of both groups respondents confirm disagreement by rating through disagree to strongly disagree in rating scale. On the contrary, about $20(16.1 \%)$ of the respondents agreed that training and development opportunities were usually offered to individuals who had good personal relationship with their immediate supervisors. Hence, 3 (2.4\%) of the respondents were not sure to decide about the issue.

In Table 9 items 6 , the respondents were requested to give their opinion about the opportunities given to the employee's interest towards TDP, $69(55.6 \%)$ of both groups of respondents disagreed that the TDP opportunities offered were based on interest of the employees and 25 (20.2\%) were replied that the program was offered based on interest of the employees. On the other hand, $30(24.2 \%)$ of the respondents were not sure to decide about the issue. Furthermore, the weighted mean score (2.69) reveals that the extent of this issue was below medium in rating scale. 
Table 10. Selection of Trainers.

\begin{tabular}{|c|c|c|c|c|c|c|c|c|c|}
\hline \multirow{3}{*}{ No } & \multirow{3}{*}{ Items } & \multirow{3}{*}{$\begin{array}{l}\text { Level of } \\
\text { Agreement }\end{array}$} & \multicolumn{6}{|c|}{ Respondents } & \multirow{3}{*}{$\begin{array}{l}\text { Weighted } \\
\text { Mean }\end{array}$} \\
\hline & & & \multicolumn{3}{|c|}{ Group I } & \multicolumn{3}{|c|}{ Group II } & \\
\hline & & & $\mathbf{F}$ & $\%$ & Mean & $\mathbf{F}$ & $\%$ & Mean & \\
\hline \multirow{6}{*}{1} & \multirow{7}{*}{$\begin{array}{l}\text { My school has clear } \\
\text { and transparent } \\
\text { criteria for selecting } \\
\text { trainers }\end{array}$} & SA & 7 & 7 & \multirow{6}{*}{2.61} & 2 & 8.3 & \multirow{6}{*}{2.67} & \multirow{6}{*}{2.62} \\
\hline & & A & 14 & 14 & & 7 & 29.2 & & \\
\hline & & UD & 24 & 24 & & - & - & & \\
\hline & & DA & 43 & 43 & & 11 & 45.8 & & \\
\hline & & SDA & 12 & 12 & & 4 & 16.7 & & \\
\hline & & ST & 100 & 100 & & 24 & 100 & & \\
\hline \multirow{6}{*}{2} & & SA & 5 & 5 & \multirow{6}{*}{2.87} & 3 & 12.5 & \multirow{6}{*}{3.21} & \multirow{6}{*}{2.94} \\
\hline & \multirow{5}{*}{$\begin{array}{l}\text { Trainers were } \\
\text { selected based on } \\
\text { competitiveness }\end{array}$} & A & 23 & 23 & & 8 & 33.3 & & \\
\hline & & UD & 26 & 26 & & 4 & 16.7 & & \\
\hline & & DA & 46 & 46 & & 9 & 37.5 & & \\
\hline & & SDA & - & - & & - & - & & \\
\hline & & ST & 100 & 100 & & 24 & 100 & & \\
\hline \multirow{6}{*}{3} & \multirow{6}{*}{$\begin{array}{l}\text { Trainers were } \\
\text { selected on the good } \\
\text { will of top level } \\
\text { leaders/managers }\end{array}$} & SA & 10 & 10 & \multirow{6}{*}{2.95} & 2 & 8.3 & \multirow{6}{*}{2.71} & \multirow{6}{*}{2.90} \\
\hline & & A & 24 & 24 & & 4 & 16.7 & & \\
\hline & & UD & 17 & 17 & & 3 & 12.5 & & \\
\hline & & DA & 49 & 49 & & 15 & 62.5 & & \\
\hline & & SDA & - & - & & - & - & & \\
\hline & & ST & 100 & 100 & & 24 & 100 & & \\
\hline \multirow{6}{*}{4} & \multirow{6}{*}{$\begin{array}{l}\text { Selection of trainers } \\
\text { was based on } \\
\text { personal relationship } \\
\text { with the TDP } \\
\text { coordinators/Leaders }\end{array}$} & SA & 8 & 8 & \multirow{6}{*}{3.42} & 3 & 12.5 & \multirow{6}{*}{3.00} & \multirow{6}{*}{3.34} \\
\hline & & A & 40 & 40 & & 6 & 25 & & \\
\hline & & UD & 38 & 38 & & 3 & 12.5 & & \\
\hline & & DA & 14 & 14 & & 12 & 50.0 & & \\
\hline & & SDA & - & - & & - & - & & \\
\hline & & ST & 100 & 100 & & 24 & 100 & & \\
\hline
\end{tabular}

Note: $\mathrm{SA}=$ strongly agree, $\mathrm{A}=$ Agree, $\mathrm{UD}=$ Undecided, $\mathrm{DA}=$ Disagree, $\mathrm{SDA}=$ strongly disagree, $\mathrm{ST}=$ Subtotal Group II $=$ Principals and supervisors, and $\mathrm{F}$ = frequency.

Concerning selection of trainers, Table 10, items 1-4 expressed the opinion of the respondents respectively. With regard to the existence of convincing and transparent criteria for selecting appropriate trainers, Table 9 , item 1 depicts that majority $70(56.4 \%)$ of both groups of respondents disagreed that their schools had clear and transparent criteria for selecting appropriate trainers. About $30(24.2 \%)$ of the respondents agreed that their respective schools had convincing and transparent criteria for selecting appropriate trainers. However, about 24 (19.4\%) of the respondents were undecided. It is indicated that majority of respondents disagreed that their respective schools have convincing and transparent criteria for selecting appropriate trainers. However, some of the woreda education officers asserted that there was a training selection criterion manual for seminars, and workshops prepared by the REB and distributed to zone education offices but in most of the training and development programs it was not used by their respective offices/schools. Moreover, the weighted mean score (2.62) the extent of the existence of convincing and transparent criteria for selecting appropriate trainers was insufficient.

A Table 10, item 2 depicts that the responses whether trainers were selected based on competitiveness or not. Majority, $55(44.4 \%)$ of the respondents disagreed that trainers were selected after applying and competing with others. Accordingly, $39(31.4 \%)$ of the respondents confirmed their agreement by rating it through strongly agree to agree. While about $30(24.2 \%)$ of the respondents were not sure about the issue. The above information indicated that majority of the respondents disagreed that appropriate trainers were selected through competitiveness. Therefore, it is possible to conclude that in some cases trainers were selected on personal basis and other relationships without applying and competing with others.

Table 10, item 3 reported whether the selection of trainers was on the good will of top level leaders/managers. About 64 $(51.6 \%)$ of the respondents of the respondents disagreed that trainers were selected on the good will of top- level managers. While, $20(16.1 \%)$ of the respondents were not sure that trainers were selected on the good will of top-level leaders/managers. On the contrary, $40(32.3 \%)$ of the respondents agreed that trainers were selected on the good will of top-level leaders/managers. This indicates that trainers were sometimes selected by the good will of top-level leaders/managers. Moreover, the weighted mean score (2.90) shows that the extent of the selection of trainers on the good will of top level leaders was below average in rating scale. From the above finding we can conclude that in some of the trainings of the education departments, sometimes trainers were selected by the good will of top-level managers/boss

As it is indicated in Table 10, item 4 respondents were further requested to identify their opinions whether trainers were selected through their personal relationships with the training and development coordinators or experts. A majority, $57(46.0 \%)$ of the total respondents confirmed their agreement by rating it through strongly agree to agree. While, $41(33.0 \%)$ of total respondents were not sure that trainers were selected through their personal relationship with 
training and development coordinators or managers.

About 26 (21\%) of both groups of respondents disagreed that trainers were selected through personal relationships with the training and development experts or managers.
Moreover, the weighted mean score (3.34) reveals that the degree of selecting trainers through their personal relationships with the training and development coordinators or experts was above average in rating scale.

Table 11. Selection of Contents.

\begin{tabular}{|c|c|c|c|c|c|c|c|c|}
\hline \multirow{3}{*}{ No } & \multirow{3}{*}{ Item } & \multirow{3}{*}{$\begin{array}{l}\text { Level of } \\
\text { Agreement }\end{array}$} & \multicolumn{6}{|c|}{ Respondents } \\
\hline & & & \multicolumn{2}{|c|}{ Group I } & \multicolumn{2}{|c|}{ Group II } & \multicolumn{2}{|l|}{$\mathbf{T N}$} \\
\hline & & & $\mathbf{F}$ & $\%$ & $\mathbf{F}$ & $\%$ & $\mathbf{F}$ & $\%$ \\
\hline \multirow{6}{*}{1} & \multirow{6}{*}{$\begin{array}{l}\text { Trainees through their } \\
\text { representatives } \\
\text { participated in the } \\
\text { selection of contents }\end{array}$} & SA & - & - & - & - & - & - \\
\hline & & A & 7 & 7 & 2 & 8.3 & 9 & 7.3 \\
\hline & & UD & 28 & 28 & 5 & 20.8 & 33 & 26.6 \\
\hline & & DA & 55 & 55 & 14 & 58.4 & 69 & 55.6 \\
\hline & & SDA & 10 & 10 & 3 & 12.5 & 13 & 10.5 \\
\hline & & ST & 100 & 100 & 24 & 100 & 124 & 100 \\
\hline \multirow{6}{*}{2} & \multirow{6}{*}{$\begin{array}{l}\text { TDP coordinators } \\
\text { selected the content of } \\
\text { the training programs }\end{array}$} & SA & 9 & 9 & 7 & 29.2 & 16 & 12.9 \\
\hline & & A & 47 & 47 & 13 & 54.2 & 60 & 48.4 \\
\hline & & UD & 27 & 27 & - & - & 27 & 21.8 \\
\hline & & DA & 17 & 17 & 4 & 16.7 & 21 & 16.9 \\
\hline & & SDA & - & - & - & - & - & - \\
\hline & & ST & 100 & 100 & 24 & 24 & 124 & 100 \\
\hline \multirow{6}{*}{3} & \multirow{6}{*}{$\begin{array}{l}\text { The school selected the } \\
\text { content of the training } \\
\text { and development } \\
\text { programs based on MOE } \\
\text { directives }\end{array}$} & SA & - & - & - & - & - & - \\
\hline & & A & 27 & 27 & 6 & 25 & 33 & 26.6 \\
\hline & & UD & 33 & 33 & 3 & 12.5 & 36 & 29.0 \\
\hline & & DA & 35 & 35 & 13 & 54.2 & 48 & 38.7 \\
\hline & & SDA & 5 & 5 & 2 & 8.3 & 7 & 5.6 \\
\hline & & ST & 100 & 100 & 24 & 100 & 124 & 100 \\
\hline
\end{tabular}

Note: $\mathrm{SA}=$ strongly agree, $\mathrm{A}=$ Agree, $\mathrm{UD}=$ Undecided, $\mathrm{DA}=$ Disagree, $\mathrm{SDA}=$ strongly disagree, $\mathrm{ST}=\mathrm{Subtotal}, \mathrm{TN}=$ total number, Group $\mathrm{I}=\mathrm{Teachers}$, Group II = Principals and supervisors, and $\mathrm{F}=$ frequency.

Accordingly, item 1 reported the majority 69 (55.6\%) of the respondents disagreed that trainees were participated in the selection of contents. About $13(10.5 \%)$ of respondents were strongly disagree. In the other hand, $33(26.6 \%)$ of the respondents were not sure about the issue that trainees were participated in the selection of contents. While, only $9(7.3 \%)$ of the respondents agreed that trainees participated in the selection of contents, which implies that trainees didn't participate in the selection of contents.

Based, on the above information we can conclude that usually trainees did not participate in the selection of the contents of the training and development programs.

Table 11, item 2 depicted the opinion of respondents whether the training and development program coordinators selected the contents of the training and development programs. Accordingly majority $76(61.3 \%)$ of the respondents agreed that training coordinators selected the contents of the training and development programs. Relatively, Second majority 27 (21.8\%) of the respondents were not sure that the training coordinators selected the contents of the training and development programs. In the contrary, $21(16.9 \%)$ of the respondents disagreed that the training and development coordinators selected the contents. The above information indicated that considerable population of the respondents agreed that training and development coordinators selected the contents of the training programs.

Table 11 item 3 also depicted responses whether the TDP contents are selected based on the MoE directives or not. Majority $55(44.4 \%)$ of the respondents were confirmed that it is not based on the $\mathrm{MoE}$ directives. On the other hand 36 $(29.0 \%)$ of the respondents responded that they were not sure about the issue. However, $33(26.6 \%)$ of the respondents agreed that the TDP contents were based on the MoE directives.

Table 12. Techniques and ways of Training and Development Programs.

\begin{tabular}{|c|c|c|c|c|c|c|c|c|}
\hline \multirow{3}{*}{ No } & \multirow{3}{*}{ Items } & \multirow{3}{*}{$\begin{array}{l}\text { Level of } \\
\text { agreement }\end{array}$} & \multicolumn{6}{|c|}{ Respondents } \\
\hline & & & \multicolumn{2}{|c|}{ Group I } & \multicolumn{2}{|c|}{ Group II } & \multicolumn{2}{|l|}{ TN } \\
\hline & & & $\mathbf{F}$ & $\%$ & $\mathbf{F}$ & $\%$ & $\mathbf{F}$ & $\%$ \\
\hline \multirow{6}{*}{1} & \multirow{6}{*}{$\begin{array}{l}\text { In-service program was } \\
\text { used as off-the- job } \\
\text { techniques }\end{array}$} & SA & 8 & 8 & 2 & 8.3 & 10 & 8.1 \\
\hline & & A & 57 & 57 & 13 & 54.2 & 70 & 56.4 \\
\hline & & UD & 29 & 29 & 7 & 29.2 & 36 & 29.0 \\
\hline & & DA & 6 & 6 & 2 & 8.3 & 8 & 6.5 \\
\hline & & SDA & - & - & - & - & - & - \\
\hline & & ST & 100 & 100 & 24 & 100 & 124 & 100 \\
\hline \multirow{5}{*}{2} & \multirow{5}{*}{$\begin{array}{l}\text { Regular program in } \\
\text { higher education used as } \\
\text { one technique }\end{array}$} & SA & - & - & - & - & - & - \\
\hline & & A & 34 & 34 & 7 & 29.2 & 41 & 33 \\
\hline & & UD & 23 & 23 & 5 & 20.8 & 28 & 22.6 \\
\hline & & DA & 43 & 43 & 12 & 50.0 & 55 & 44.4 \\
\hline & & SDA & - & - & - & - & - & - \\
\hline
\end{tabular}




\begin{tabular}{|c|c|c|c|c|c|c|c|c|}
\hline \multirow{3}{*}{ No } & \multirow{3}{*}{ Items } & \multirow{3}{*}{$\begin{array}{l}\text { Level of } \\
\text { agreement }\end{array}$} & \multicolumn{6}{|c|}{ Respondents } \\
\hline & & & \multicolumn{2}{|c|}{ Group I } & \multicolumn{2}{|c|}{ Group II } & \multicolumn{2}{|l|}{ TN } \\
\hline & & & $\mathbf{F}$ & $\%$ & $\mathbf{F}$ & $\%$ & $\mathbf{F}$ & $\%$ \\
\hline & \multirow{7}{*}{$\begin{array}{l}\text { Coaching techniques } \\
\text { used as on-the-job } \\
\text { program }\end{array}$} & ST & 100 & 100 & 24 & 100 & 124 & 100 \\
\hline \multirow{6}{*}{3} & & SA & 13 & 13 & 9 & 37.5 & 22 & 17.7 \\
\hline & & A & 53 & 53 & 12 & 50.0 & 65 & 52.4 \\
\hline & & UD & 20 & 20 & 1 & 4.2 & 21 & 16.9 \\
\hline & & DA & 14 & 14 & 2 & 8.3 & 16 & 12.9 \\
\hline & & SDA & - & - & - & - & - & - \\
\hline & & ST & 100 & 100 & 24 & 100 & 124 & 100 \\
\hline \multirow{6}{*}{4} & \multirow{6}{*}{$\begin{array}{l}\text { Mentoring program used } \\
\text { as on-the-job program }\end{array}$} & SA & 7 & 7 & 15 & 62.5 & 22 & 17.7 \\
\hline & & A & 49 & 49 & 4 & 16.7 & 53 & 42.8 \\
\hline & & UD & 12 & 12 & 2 & 8.3 & 14 & 11.3 \\
\hline & & DA & 31 & 31 & - & - & 31 & 25 \\
\hline & & SDA & 1 & 1 & 3 & 12.5 & 4 & 3.2 \\
\hline & & ST & 100 & 100 & 24 & 100 & 124 & 100 \\
\hline
\end{tabular}

Table 12, items 1-4 indicated what kind of training and development methods were used in the secondary schools.

Accordingly, item 1 depicts that whether in-service programs were used as off-the-job training and development techniques in their respective schools/departments to train and develop employees and heads. Majority, 80 (64.5\%) of the respondents agreed that their schools used in-service training programs as off-the-job training and development technique. About $8(6.5 \%)$ of the respondents not believed that their departments used in service training program for training individual employees and leaders. While about 36 $(29.0 \%)$ of the respondents replied "no response". These indicated that majority of the respondents disagreed that their respective school/departments used in service programs as off-the-job training techniques.

As it is shown in Table 13, in item 2 both groups respondents were further requested to respond whether their departments used attending regular program in higher education as off-the- job training and development method. An overwhelming majority $55(44.4 \%)$ of the respondents disagreed that their schools used learning regular education as off-the- job training and development technique. About 41 $(33.0 \%)$ of the respondents believed that their respective departments used it as a technique. However, about 28 $(22.6 \%)$ of the respondents commented nothing. Majority of the respondents indicated that regular program in higher institutions had not been mainly practiced in their education departments. From the above information we can conclude that attending regular program in higher education was rarely used as off-the-job training and development technique. The interview with the principals and coordinators/experts also revealed that there is no organized, systematic and adequate effort done to train and develop teachers' employees on such technique. The information collected through document analysis reveals the same fact that offices sponsored individuals to learn in higher education institutes when they applied and competed after having the access to the colleges/universities.

As it was depicted in Table 13, in item 3 and 4 respondents were asked which of on-the- job training and development techniques were most often applicable in their departments. Accordingly, item 3 indicated the responses towards coaching technique. An overwhelming majority 87 (70.1\%) of the respondents agreed that coaching technique was the most often applicable in their offices. However, about 16 $(12.9 \%)$ of the respondents disagreed. While about 21 $(16.9 \%)$ of the respondents were not sure about the issue.

As it was observed in Table 13, in item 4 respondents indicated their opinion with regards to the mentoring technique of the on-the-job training and development. Accordingly, majority $75(60.5 \%)$ of the respondents agreed that mentoring technique was the most applicable technique of on-the-job training and development method in their respective schools/departments. However, few 35 (28.2\%) of the respondents disagreed. While about $14(11.3 \%)$ of the respondents were not sure about the issue. Majority of the respondents agreed that mentoring technique was one of the techniques used as on-the-job training and development method in their respective schools/departments.

From the above information it is possible to conclude as proposed by Getachew, (1998), that mentoring was one of the applicable on-the-job training and development methods in their respective departments or offices. However, it is mainly depended on the willingness of individuals and through their personal relationships.

\subsubsection{Major Problems/Constraints to Prepare and Implement HRTDP}

As it is observed in Table 13 respondents were requested to indicate the major constraints faced by their respective secondary schools to prepare and implement training and development programs to teachers and administrative staff. Majority of the respondents indicated their responses.

According to the responses, the percentages of 15 listed problems were ranked corresponding to the percentage of all responses in the table. Accordingly, some of the basic constraints include absence of monitoring and evaluation of training and development programs and low attention paid by the top level managers towards HRTD 107 (86.3\%), absence of training and development needs assessment $103(83.1 \%)$, allocation of insufficient time in relation to contents 102 $(82.3 \%)$, lack of trainer capacity $101(81.5 \%)$, absence of transparent and clear long-term TDP guide lines/directives 99 (79.8\%), lack of proper orientation/induction program to new recruits and new position holders, selection of inappropriate 
trainees and trainers $100(80.6 \%)$, lack of adequate budget, problems of keeping records of all TDPs and lack of commitment of higher officials $98(79 \%)$ respectively were ranked from $1^{\text {st }}$ to $11^{\text {th }}$ in ascending order of the main constraints to prepare and implement TDPs based on the responses replied by the respondents.

Table 13. Major Problems of HRTDPs Observed in the Selected Study Area.

\begin{tabular}{|c|c|c|c|c|c|c|}
\hline \multirow{3}{*}{ No } & \multirow{3}{*}{ Items } & \multicolumn{4}{|c|}{ Respondents } & \multirow{3}{*}{ Ranks } \\
\hline & & \multirow{2}{*}{$\begin{array}{l}\text { Group I } \\
\text { F }\end{array}$} & \multirow{2}{*}{$\begin{array}{l}\text { Group II } \\
\text { F }\end{array}$} & \multirow{2}{*}{ Total N } & \multirow{2}{*}{$\%$} & \\
\hline & & & & & & \\
\hline 1 & Absence of training and development needs assessment practices & 86 & 17 & 103 & 83.1 & 3 \\
\hline 2 & Absence of transparent and clear short term TDP guidelines / directives/ & 83 & 10 & 93 & 75 & 14 \\
\hline 3 & Absence of transparent and clear long- term TDP guidelines / directives/ & 77 & 22 & 99 & 79.8 & 9 \\
\hline 4 & Allocation of insufficient time in relation to contents & 89 & 13 & 102 & 82.3 & 4 \\
\hline 5 & Lack of proper orientation program to new recruits and new position holders & 86 & 14 & 100 & 80.6 & 6 \\
\hline 7 & Lack of trainers capacity & 84 & 17 & 101 & 81.5 & 5 \\
\hline 8 & Absence of monitoring and evaluation of training and development programs & 86 & 21 & 107 & 86.3 & 1 \\
\hline 9 & Lack of commitment of higher officials & 82 & 16 & 98 & 79 & 10 \\
\hline 10 & Giving priority to other activities due to shortage of time & 90 & 7 & 97 & 78.2 & 13 \\
\hline 11 & Absence of planning and clear training objectives & 82 & 11 & 93 & 75 & 14 \\
\hline 12 & Problems of keeping records of all training and development programs & 84 & 14 & 98 & 79 & 10 \\
\hline 13 & Low attention paid by top-level management towards HRTD & 86 & 21 & 107 & 86.3 & 1 \\
\hline 15 & Selection of inappropriate trainers & 87 & 13 & 100 & 80.6 & 6 \\
\hline
\end{tabular}

Key: $\mathrm{F}=$ Frequency, $\mathrm{N}=$ Number, and $\mathrm{R}=$ Rank, Group $\mathrm{I}=$ Teachers $(\mathrm{N}=100)$ and Group $\mathrm{II}=$ Principals and Supervisors $(\mathrm{N}=24)$.

\section{Conclusions}

1. Regarding personal characteristics of the respondents, majority, $101(75.9 \%)$ of the respondents were male revealing that the participation of female in these position in the departments/offices was low. Most of the respondents have adequate qualification in relation to the required jobs. However, the existence of diploma graduates in the technical drawing field indicated that there is a need for upgrading them in the future. With regard to the age distribution, the majority $53.4 \%$ of the respondents were in the age of group of between 26-30 and 31-35 years. Very few respondents were within the age group of 40 and above years.

2. Concerning inclusion of HRTD plans with strategic plans, it was investigated that, the HRTD plans were not incorporated in strategic plans.

3. With regard to the status of training and development needs assessment it was found that mostly the departments/schools didn't conduct TD need assessment, that there was no systematic needs assessment conducted in most of the secondary schools.

4. Concerning objectives of HRTDP delivered, it was found that majority $63(63.7 \%)$ of the respondents confirmed that in the TDPs, they have attended, objectives had been set before the preparation and implementation of the program. However, in some of the programs objectives were not presented to trainees in a systematic way.

5. Regarding focus of the training and development programs it was found out that majority of the respondents believed that the main focus of the programs were to introduce new methods, procedures, etc. to teachers and administrative staff. Majority, of the respondents also asserted that the main focus of the TDPs was to improve the performance of employees and leaders. Even though the majority of the respondents agreed on the issue, some claimed that there was no adequate effort done to improve the job performance of teachers and co-workers.

6. With regard to the selection of trainees, trainers and contents it was found out that majority of the respondents agreed on the absence of clear and transparent selection criteria for selecting trainees and trainers. However, training and development opportunities offered to individuals who have good personal relationships with immediate heads. In most cases the findings also indicated that the appropriate trainers were not selected through competitiveness.

7. With regard to on-the-job training and development techniques employed, it was found that coaching technique was the most often applicable on-the-job training and development method, however, it did not systematically applied as a method but as one of the work relationship. Most of the respondents confirmed that mentoring was one of the applicable on-the-job training and development methods in their respective secondary schools. However, it was mainly depended on the willingness of individuals and determined through their personal relationship.

8. Concerning keeping records of TDP and practice of monitoring and evaluating effectiveness of the TDP delivered; it was found the education departments/ secondary schools had no well organized system of keeping records of all training and development programs delivered and majority of the respondents also confirmed that there were no systematic practices of evaluating the effectiveness of training and development programs conducted in the departments/ 
secondary schools.

9. Regarding the constraints to arrange and implement TDP, the findings also reveals that among the major constraints/problems in the departments to prepare and implement training and development programs, some of them were: low attention paid by the top level managers towards TDP, lack of commitment of higher officials, absence of training and development needs assessment, absence of clear and transparent long-term TDP guide-lines, lack of proper orientation, lack of proper orientation/induction, absence of monitoring and evaluating TDPs, lack of adequate budget, selection of inappropriate trainees and trainers, allocation of insufficient time, problem of keeping records of all the TDPs and giving priority to other activities were ranked accordingly.

\section{Recommendations}

Based on the findings and conclusions of the study the following recommendations are suggested.

1. Training and development programs could meet their intended objectives if and only if they are based on a systematic training and development needs assessment. Therefore, to avoid wastages of human, material, financial and time resources and the duplication of efforts, in secondary schools/departments/, training and development needs assessment has to be carried out in cooperation with all stake holders. Individuals should identify their needs, different mechanisms of collecting information has to be used by employing organizational, job (task) and person analysis.

2. Conducting TDP without plan led to wastage of resources and failure to meet the objectives of the programs and organizational goals. Therefore, it is recommended that at the education secondary schools, departments/offices, short and long-term plan should be prepared and designed for their teachers/employees/ and educational leaders and be incorporated in the strategic plans. To avoid duplication and wastage the annual plans of the schools/educational offices/ should be discussed, commented and amended by the stake holders, who are at the school.

3. To achieve the desired goals of the training and development programs objectives should be clear and precise to indicate the expected outcomes and these objectives should have presented in a systematic way to the trainees. Therefore, in delivering the training and development programs should be based on the objective reality of the secondary schools and situations.

4. The absence of clear and transparent selection criteria for trainees and trainers paved the way of training and top-level educational leaders to select trainers and to offer training and development opportunities based on their personal relationships and good will. However, this harmed the morals and initiatives of others. Therefore, it is recommended that secondary schools and education offices should have clear and transparent criteria to select trainees and trainers that govern everybody in the schools irrespective to his/her position. So based on MoE/REB, the education departments at their level should develop TDP directives concerning short-term or long-term training and development programs. Moreover, training and development opportunities should be offered to appropriate trainees and trainers selected to provide effective and efficient TDP to bring change in work behavior and better performance.

5. It is not possible to suggest that TDP could meet their intended objectives with the absence of evaluation practices towards their effectiveness and outcomes. Therefore, it is recommended that the secondary schools and education offices should have a scheme to evaluate the TDP at different procedures/stages in relation to cause of the programs, work behaviors, achievement of objectives and outcomes or effects such system should also be institutionalized. With regard to the time frame, the offices should use the appropriate time of evaluation depending on the nature of TDPs.

\section{References}

[1] Krung. S. E. (1992). "Instructional Leadership: A constructive Perspective." Educational Administration Quarterly vol. 28. No. 3, pp 430-443.

[2] Chandan, J. S. (2003). Management Concepts and Strategies. New Delhi: Vikas Publishing House Pvt. Ltd.

[3] Ayalew Shibeshi (1991). Approaches to Educational Organization and Management Teaching material: Addis Ababa University (Unpublished).

[4] Heneman, and L. D. Dyer, (1996). Personnel/human resources and management, 4th ed. New Delhi: Universal Book Stall.

[5] Swanson, R. A. (1995). Human Resource Development: Performance is the Key. Human Resource Development Quarterly, 62 (2), 207-213.

[6] Mc Lagan, P. A. (1989). Systems Model 2000: Matching Systems Theory to Future HRD Issues. lexandria, VA: ASTD Press.

[7] Desimon, L. R, Werner, M. J, Harris, M. D (2002). Human Resource Development ( $3^{\text {rd }}$ ed) Thomson; south - western publisher

[8] Lewin and Janet, (1999). Educational Innovation in Developing Countries. London: Macmillan Press Ltd.

[9] Fiona E. and Alan G. (2005). "HRM Practices and Employees' Attitudes: different measures-different results", Personnel Review, Vol. 34 No. 5, pp. 534-569.

[10] Tamirat (2010). Employees' opinion about human resource development practices of national bank of Ethiopia.

[11] Laird D, (1985). Approaches to Training and Development $\left(2^{\text {nd }}\right.$ ed $)$.

[12] Cohen, L. e. (2007). Research Method in Education. Oxon: Routledge. 
[13] Abiy (2009). Introduction to Research Methods. Addis Ababa University.

[14] James, G., \& Rodney, R. (1991). Educational Administration and Policy. Boston: Allyn and Bacon.

[15] Mathis, R. L. and J. H. Jackson, (1997). Human resource management, $8^{\text {th }}$ ed. Minneapolis: West Publishing Co.
[16] Gomez-Mejia and L. Cardy, (1995). Managing Human Resources. Englewood Cliff: Prentice Hall.

[17] Getachew Minas, (1998). "Human resource management in the Ethiopian public sector" Adis Ababa.

[18] Armstrong, M., (2001). A handbook of human resource management practice, 8th ed. London. Kogan page Limited. 